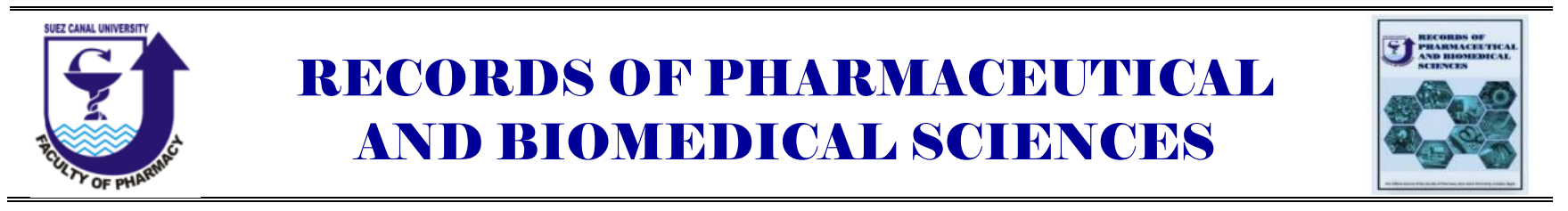

\title{
Biological Activities of Different Species of the Genus Phyllostachys
}

\author{
Ahmed K. Ibrahim, Reda F. Abdelhameed, Eman S. Habib, Safwat A. Ahmed, \\ Amany K. Ibrahim, Jihan M. Badr * \\ Department of Pharmacognosy, Faculty of Pharmacy, Suez Canal University, Ismailia 41522, Egypt
}

Received on: 02-2-2021

Revised on: 10-2-2021

Accepted on: 15-2-2021

*Correspondence Author:

Tel.: +201091332451

E-mail:

jihanbadr2010@hotmail.com

\begin{abstract}
The Genus Phyllostachys (bamboo) is widespread all over the world. Through history, bamboo has been an important source of food and medicine in China and South East Asia. Almost all parts of the bamboo plant such as rhizome, culm and bark shaving, shoots, leaves, roots and seeds are having clinical applications. Recently, bamboo gained attention around the world because of its nutritive and therapeutic values and the important role it plays in the food, pharmaceutical and cosmeceutical industry. Bamboo leaves and shoots have tremendous therapeutic potential and can provide health care in a safe and ecofriendly way. In this review, we summarize the most important biological activities of different species of the genus Phyllostachys.
\end{abstract}

Keywords: Phyllostachys; different species; biological activities.

\section{Introduction}

Traditional medicine around the world is extensively based on herbal medicine. The use of the whole extract or the active ingredients obtained from plants have long been used before the discovery of modern medicine. (Mathur \& Hoskins, 2017). Accordingly, exploration and pharmacological screening of the active ingredients isolated from plants can provide us with the basis for developing lead molecules through the discovery of herbal drugs. (Koparde et al., 2019). Plants are the most important source of natural medicine, because of their chemical and structural diversity and the biodiversity of their components. Till now, plants are considered as the most important source of novel biologically active compounds which are isolated from plants or even semi-synthesized from naturally derived ingredients. Despite the current obsession with synthetic chemistry as a vehicle for important drug development and processing, the contribution of plants to the treatment and prevention of diseases is still enormous. $11 \%$ of drugs considered as basic and essential by the world health organization (WHO) were solely of flowering plant origin. (Veeresham, 2012).

Bamboo plant is commonly used in folk medicine for their antipyretic, anti-inflammatory, and diuretic effect (Chongtham et al., 2011). The therapeutic use of bamboo leaves for treating arteriosclerosis, hypertension, cardiovascular disease, and cancer have been also reported (Park et al., 2007). Additionally, antioxidant and angiotensin-converting enzyme inhibition activity were also proven (Park $\boldsymbol{e t}$ al., 2010; Zhang $\boldsymbol{e t}$ al., 2008). In this review we will summarize the most important reported biological activities of different species of the genus Phyllostachys. 


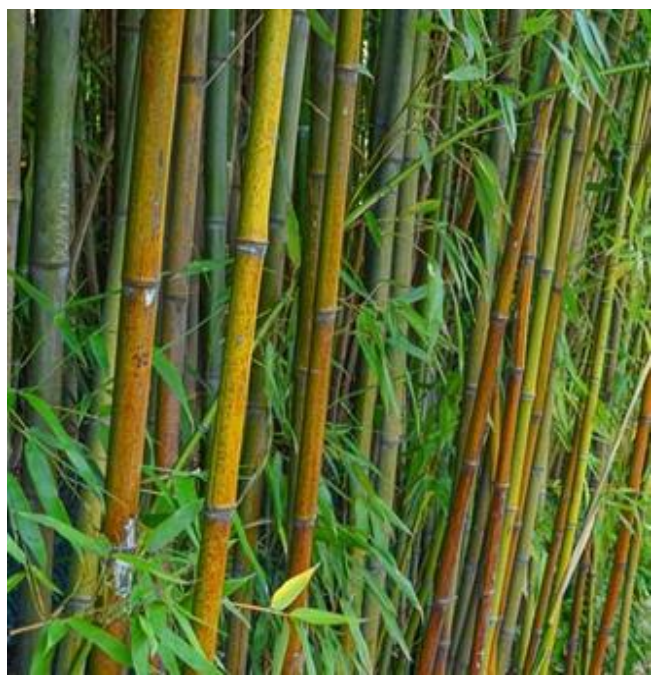

Phyllostachys viridiglaucescens

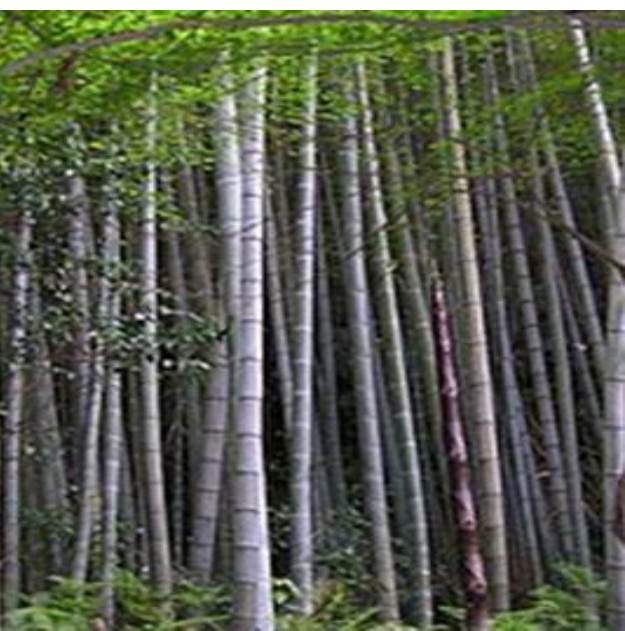

Phyllostachys edulis

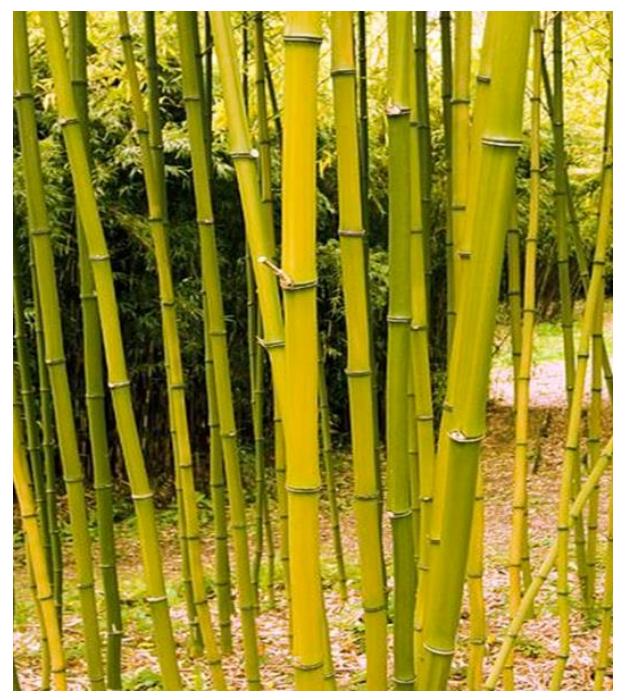

Phyllostachys bambusoides

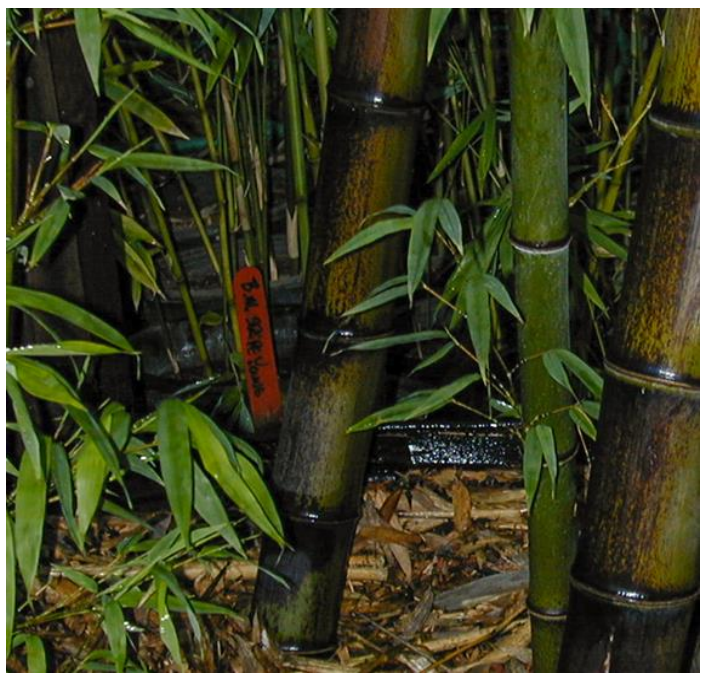

Phyllostachys nigra

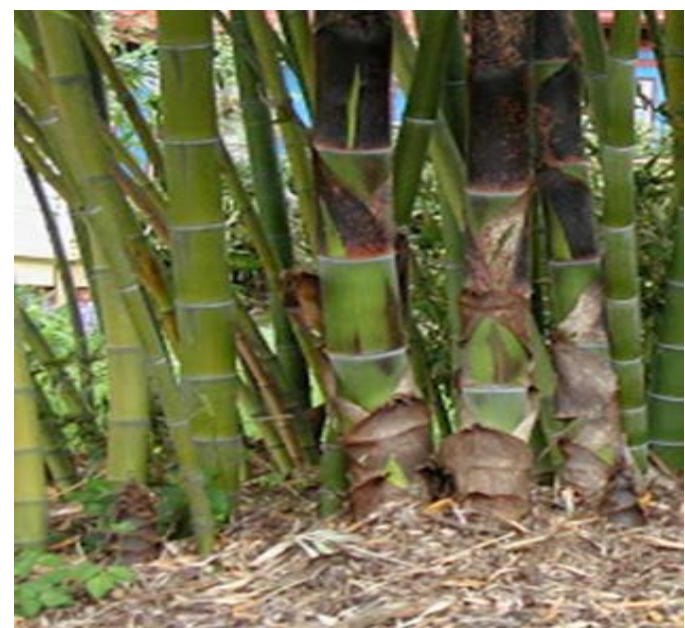

Phyllostachys heterocycla

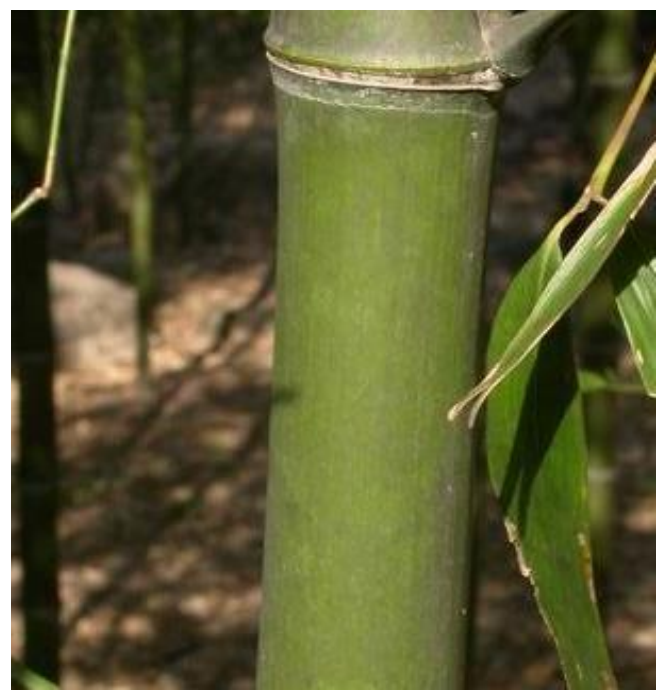

Phyllostachys prominens

Figure 1: Photoes of selected species of the genus Phyllostachys which possess proved biological activities (https://www.gardenia.net/plant/phyllostachys) 
Table 1. Biological activities reported in genus Phyllostachys:

\begin{tabular}{|c|c|c|c|}
\hline \multicolumn{4}{|l|}{ Anticancer activity } \\
\hline Active Compounds / extracts & Details & Species & Reference \\
\hline Tricin flavonoid & $\begin{array}{l}\text { in vitro activity against human-derived malignant } \\
\text { MDAMB- } 468 \text { breast cancer cells and human } \\
\text { MDA-MB- } 468 \text { breast cancer cells. }\end{array}$ & P. nigra var. henonis & $\begin{array}{l}\text { (Hudson et } \\
\text { 2000; Cai et } \\
\text { 2004; Jiao et } \\
\text { 2007) }\end{array}$ \\
\hline Ethanolic extract & $\begin{array}{l}\text { Potent effect against the development of } 7,12 \\
\text { dimethylbenz[a]anthracene (DMBA)-induced } \\
\text { breast cancer model in female rats. }\end{array}$ & P. edulis & (Lin et al., 2008) \\
\hline \multicolumn{4}{|c|}{ Antibacterial and Antimicrobial activity } \\
\hline 2,6-dimethoxy- $p$-benzoquinone & Activity against Gram-positive bacteria & P. heterocycla var. pubescens & $\begin{array}{l}\text { (Nishina et al., } \\
\text { 1991) }\end{array}$ \\
\hline Supercritical $\mathrm{CO}_{2}$ Extract & $\begin{array}{l}\text { Antimicrobials and antioxidants as ethoxyquin, a } \\
\text { sesquiterpene, and a cyclohexanone derivative } \\
\text { were identified. }\end{array}$ & P. heterocycla & $\begin{array}{l}\text { (Quitain et al., } \\
\text { 2004) }\end{array}$ \\
\hline Two peptides Pp-AMP 1 and Pp-AMP 2 & $\begin{array}{l}\text { Antimicrobial activities against some pathogenic } \\
\text { bacteria and fungi }\end{array}$ & P. pubescens & $\begin{array}{l}\text { (Fujimura et al., } \\
\text { 2005) }\end{array}$ \\
\hline $\begin{array}{l}\text { The essential oils obtained by steam } \\
\text { distillation }\end{array}$ & $\begin{array}{l}\text { Active against Staphylococcus epidermidis and } E \text {. } \\
\text { coli }\end{array}$ & $\begin{array}{l}\text { - P. heterocycla cv. Pubescens } \\
\text { - P. heterocycla cv. Gracilis, } \\
\text { - P. heterocycla cv. Heterocycla } \\
\text { - P. kwangsiensis }\end{array}$ & (Jin et al., 2011) \\
\hline Dichloromethane extract & $\begin{array}{l}\text { Antibacterial activity against Staphylococcus } \\
\text { aureus }\end{array}$ & P. pubescens & $\begin{array}{l}\text { (Tanaka et al., } \\
\text { 2011) }\end{array}$ \\
\hline $\begin{array}{l}\text { - Stigmasterol. } \\
\text {-Dihydrobrassicasterol. }\end{array}$ & Inhibited the growth of Staphylococcus aureus. & P.pubescens & $\begin{array}{l}\text { (Tanaka et al., } \\
\text { 2013) }\end{array}$ \\
\hline Ethanol and the hot water extracts & $\begin{array}{l}\text { Antibacterial activity against Staphylococcus } \\
\text { aureus }\end{array}$ & P. pubescens & $\begin{array}{lll}\text { (Tanaka et } & \text { al., } \\
\text { 2014) } & & \\
\end{array}$ \\
\hline $\begin{array}{l}\text { - Tricosane, cedrol. } \\
\text { - Hexadecanoic acid. }\end{array}$ & $\begin{array}{l}\text { Antibacterial activities against Gram-negative } \\
\text { bacteria Escherichia coli, Gram-positive bacteria } \\
\text { Bacillus subtilis and Saccharomyces cerevisiae. }\end{array}$ & P. heterocycla cv. pubescens & (Tao et al., 2018) \\
\hline Essential oils from leaves & $\begin{array}{l}\text { Effect against Gram-positive (Bacillus subtilis and } \\
\text { Staphylococcus aureus) and Gram-negative }\end{array}$ & P. heterocycla cv. pubescens & (Tao et al., 2019) \\
\hline
\end{tabular}




\begin{tabular}{|c|c|c|c|}
\hline & $\begin{array}{l}\text { (Escherichia coli) bacteria and yeast } \\
\text { (Saccharomyces cerevisiae) by causing disruption } \\
\text { to the membrane integrity of the pathogen. }\end{array}$ & & \\
\hline Water-soluble neutral polysaccharides & $\begin{array}{l}\text { Growth inhibition against } E \text {. coli, S. aureus and } B \text {. } \\
\text { subtilis }\end{array}$ & P. pubescens Mazel & (Xiao et al., 2020) \\
\hline \multicolumn{4}{|l|}{ Antioxidant activity } \\
\hline - Tricin & $\begin{array}{l}\text { Antioxidative activity was evaluated by the } \\
\text { peroxide value (POV) method. }\end{array}$ & P. pubescens & $\begin{array}{l}\text { (Katsuzaki et al., } \\
\text { 1999) }\end{array}$ \\
\hline $\begin{array}{l}\text { - Chlorogenic acid. } \\
\text { - Caffeic acid. } \\
\text { - Luteolin-7-glucoside }\end{array}$ & $\begin{array}{l}\text { Antioxidant activity related to free radical } \\
\text { scavenging activity while the prooxidant activity } \\
\text { resulted from the reducing power of extract } \\
\text { phenolic compounds in presence of transitional } \\
\text { metal ions. }\end{array}$ & P. nigra Var. Henonis & (Hu et al., 2000) \\
\hline $\begin{array}{l}\text { - 3-O-(3'-methylcaffeoyl) quinic acid. } \\
\text { - 5-O-caffeoyl-4-methylquinic acid. } \\
\text { - 3-O-caffeoyl-1-methylquinic acid. }\end{array}$ & $\begin{array}{l}\text { Strong antioxidant activity measured by } \\
\text { scavenging the stable 1,1-dipheny 1-2- } \\
\text { picrylhydrazyl (DPPH) free radical and the } \\
\text { superoxide anion radical }\left(\mathrm{O}^{2-}\right) \text { in the } \\
\text { xanthine/xanthine oxidase assay system. }\end{array}$ & P. edulis & (Kweon et al., 2001) \\
\hline Phyllostadimer A & Strongly inhibited liposomal lipid peroxidation & P. edulis & (Suga et al., 2003) \\
\hline Lignophenol derivatives & $\begin{array}{l}\text { Potent neuroprotective activity against oxidative } \\
\text { stress }\end{array}$ & P. bambusoides & (Akao et al., 2004) \\
\hline n-butanol soluble extract & $\begin{array}{l}\text { Strong antioxidant activity measured by } \\
\text { scavenging the stable DPPH free radical }\end{array}$ & $\begin{array}{l}\text { P. pubescens } \\
\text { P. bambusoides }\end{array}$ & (Mu et al., 2004) \\
\hline Supercritical $\mathrm{CO}_{2}$ Extract & $\begin{array}{l}\text { Antimicrobials and antioxidants as ethoxyquin, a } \\
\text { sesquiterpene, and a cyclohexanone derivative } \\
\text { were identified. }\end{array}$ & P. heterocycla & $\begin{array}{l}\text { (Quitain et al., } \\
\text { 2004) }\end{array}$ \\
\hline $\begin{array}{l}\text { Luteolin } \quad 6-C-\left(6^{\prime \prime}-O-\text { trans- }\right. \\
\text { caffeoylglucoside })\end{array}$ & $\begin{array}{l}\text { Antioxidative activity measured in } \\
\text { Photochem }{ }^{\circledR} \text { apparatus }\end{array}$ & P. nigra & (Jung et al., 2007) \\
\hline $\begin{array}{l}\text { - Orientin. } \\
\text { - Homoorientin. } \\
\text { - Vitexin. } \\
\text { - Isovitexin. }\end{array}$ & $\begin{array}{l}\text { Strong antioxidant activity and inhibitory efficacy } \\
\text { on transition metal ions and in vitro free radicals } \\
\text { inducing deterioration of macromolecules. }\end{array}$ & P. nigra var. henonis & $\begin{array}{l}\text { (Hu, et al., 2000; } \\
\text { Zhang et al., 2008) }\end{array}$ \\
\hline Ethyl acetate and butanol fractions of & High antioxidant activity using a 2,2- diphenyl-1- & P. pubescens & (Park et al., 2010) \\
\hline
\end{tabular}




\begin{tabular}{|c|c|c|c|}
\hline methanolic extract & picrylhydrazyl (DPPH) radical scavenging assay & P. nigra & \\
\hline $\begin{array}{l}\text { Luteolin } \quad 6-C-\left(6^{\prime \prime}-O-\text { trans- }\right. \\
\text { caffeoylglucoside })\end{array}$ & $\begin{array}{l}\text { Significant attenuation of the negative effects of 1- } \\
\text { buthionine-(S,R)-sulfoximine (BSO) plus } \\
\text { glutamate or hydrogen peroxide to RGC-5 cells. } \\
\text { Replenishment of the reduced glutathione level. }\end{array}$ & P. nigra & (Lee et al., 2010) \\
\hline Bamboo shoot extracts & Strong DPPH radical scavenging activity. & $\begin{array}{l}\text { P. pubescens } \\
\text { P. nigra }\end{array}$ & (Park et al., 2011) \\
\hline $\begin{array}{l}\text { The essential oils obtained by steam } \\
\text { distillation }\end{array}$ & $\begin{array}{l}\text { Antioxidant activity using a } 2,2-\text { diphenyl-1- } \\
\text { picrylhydrazyl (DPPH) radical scavenging assay }\end{array}$ & $\begin{array}{l}\text { P. heterocycla cv. Pubescens } \\
\text { P. heterocycla cv. Gracilis } \\
\text { - P. heterocycla cv. Heterocycla } \\
\text { - P. kwangsiensis } \\
\end{array}$ & (Jin et al., 2011) \\
\hline Water extracted polysaccharides & $\begin{array}{l}\text { Strong inhibitory effects on superoxide radical } \\
\text { and hydroxyl radical. }\end{array}$ & P. edulis & (Zhang et al., 2011) \\
\hline $\begin{array}{l}\text { - Trans-coniferyl alcohol. } \\
\text { - } p \text {-coumaric acid. } \\
\text { - } n \text {-feruloyl serotonin. } \\
\text { - Caffeic acid ethyl ethe. } \\
\text { - Tricin. } \\
\text { - Coumaryl alcohol. } \\
\text { - Coumaric acid ethyl ether. } \\
\text { - Ferulic acid ethyl ether }\end{array}$ & Significant DPPH radical scavenging Ability. & P. nigra & (Shang et al., 2014) \\
\hline Ethanol extracts and the hot water extracts & $\begin{array}{l}\text { Antioxidant activity measured by the following } \\
\text { assays: The ORAC assay which is based on } \\
\text { hydrogen atom transfer reactions, The ABTS } \\
\text { inhibition rates which are based on the electron- } \\
\text { transfer ability of the sample's components and } \\
\text { SOD-like activity which is based on the } \\
\text { antioxidative enzyme-like activity of the sample's } \\
\text { components. }\end{array}$ & P. pubescens & $\begin{array}{lll}\text { (Tanaka } & \text { et } & \text { al., } \\
\text { 2014) } & & \end{array}$ \\
\hline $\begin{array}{l}\text { - Amarusine A. } \\
\text { - 5-O-caffeoylquinic acid, } 3,5,3^{\prime}, 5^{\prime}-\end{array}$ & $\begin{array}{l}\text { The DPPH (1,1-diphenyl-2-picrylhydrazyl) assay } \\
\text { showed radical scavenging activity }\end{array}$ & P. prominens & (Xu et al., 2016) \\
\hline
\end{tabular}


tetramethoxy-4-hydroxyl-(8-O-cinnamyl alcohol)-7-O-glucoside.

- 4, 4', 9'-trihydroxyl-3, 5, 3', 5'tetramethoxy-7, 7'-monoepoxylignan-9-Oglucoside.

- 3,5- dimethoxy-4,4'-dihydroxyl-9-Obenzylacrylicester-phenylpropano-7- $O$ -

glucopyranoside.

- Luteolin-7-O-glucoside.

- Luteolin-8-C- $\alpha$-L-arabinose.

- Isoorientin.

- Tricin-7- $O-\beta$-D-glucoside.

- Tricin-5- $O-\beta$-D-glucoside.

- Isovitexin-2"-xylopyranoside. Water-soluble neutral polysaccharides

\section{IV- Hypolipidemic effect}

\begin{tabular}{|c|c|c|}
\hline Bamboo shoot oil (BSO) & $\begin{array}{l}\text { Significant decrease in the levels of total } \\
\text { cholesterol, triacylglycerol, low-density } \\
\text { lipoprotein-cholesterol, phytosterol, lipoprotein } \\
\text { lipase, hepatic lipase and atherogenic index in } \\
\text { serum. }\end{array}$ & $\begin{array}{l}\text { P. pubescens } \\
\text { P. nigra }\end{array}$ \\
\hline $\begin{array}{l}\text { Triterpenoid-rich extract from bamboo } \\
\text { shavings (EBS) }\end{array}$ & $\begin{array}{l}\text { Reduction of the serum total cholesterol (TC) and } \\
\text { total triglyceride (TG) levels. }\end{array}$ & P. nigra var. henonis \\
\hline
\end{tabular}

(Lu et al., 2010)

shavings (EBS)

\section{Hypoglycemic and antidiabetic activity}

\begin{tabular}{|c|c|c|c|}
\hline $\begin{array}{l}\text { Luteolin } \quad 6-C-\left(6^{\prime \prime}-O \text {-trans- }\right. \\
\text { caffeoylglucoside })\end{array}$ & $\begin{array}{l}\text { Strong aldose reductase and advanced glycation } \\
\text { end products inhibition }\end{array}$ & P. nigra & (Jung et al., 2007) \\
\hline Arabinogalactan (PBSS2) & $\begin{array}{l}\text { In vitro Caco- } 2 \text { cells assay exhibited inhibition in } \\
\text { glucose absorption in time dependent manner at a } \\
\text { relative high concentration. }\end{array}$ & P. heterocycla & (Liu et al., 2018) \\
\hline
\end{tabular}




\begin{tabular}{|c|c|c|c|}
\hline \multicolumn{4}{|l|}{ Cardiovascular activity } \\
\hline Orientin & $\begin{array}{l}\text { Significant potent cardioprotective effect on I/R- } \\
\text { and H/R-treated myocardium and cardiomyocytes. }\end{array}$ & P. nigra & (Fu et al., 2006) \\
\hline $\begin{array}{l}\text { - Triterpenoid-rich extract from bamboo } \\
\text { shavings (EBS). } \\
\text { - Friedelin. }\end{array}$ & $\begin{array}{l}\text { Reduction in the systolic pressure of } \\
\text { spontaneously hypertensive rats without affecting } \\
\text { heart rate. }\end{array}$ & P. nigra var. henonis & (Jiao et al., 2007) \\
\hline Methanolic extract & Significant ACE inhibitory activity & $\begin{array}{l}\text { P. pubescens } \\
\text { P. nigra }\end{array}$ & (Park et al., 2010) \\
\hline \multicolumn{4}{|l|}{ VII- Prebiotic activity } \\
\hline $\begin{array}{l}\text { Water-soluble } \\
\text { protein complexes }\end{array}$ & $\begin{array}{l}\text { Increasing the numbers of Bifidobacterium } \\
\text { adolescentis and Bifidobacterium bifidum, which } \\
\text { contribute to production of organic acids. }\end{array}$ & P. praecox & (He et al., 2016) \\
\hline \multicolumn{4}{|c|}{ VIII- Melanin-biosynthesis-inhibition activity } \\
\hline Ethanol extracts and the hot water extracts & $\begin{array}{l}\text { Significant inhibition on melanin biosynthesis and } \\
\text { cell proliferation of B16 melanoma cells }\end{array}$ & P. pubescens & $\begin{array}{lll}\text { (Tanaka et al., } \\
\text { 2014) }\end{array}$ \\
\hline \multicolumn{4}{|l|}{ IX- Anti-Allergy Activity } \\
\hline Ethanol extracts and the hot water extracts & $\begin{array}{l}\text { Significant inhibition of the production of IgE in } \\
\text { Peripheral Blood Lymphocytes. }\end{array}$ & P. pubescens & $\begin{array}{l}\text { (Tanaka et al., } \\
\text { 2014) }\end{array}$ \\
\hline \multicolumn{4}{|l|}{ X- $\quad$ Anti-Inflammatory Activity } \\
\hline Leaf extract and isoorientin & $\begin{array}{l}\text { High anti-inflammatory activity was examined on } \\
\text { tumor necrosis factor alpha-induced } \\
\text { overproduction of interleukin 8, vascular } \\
\text { endothelial growth factor, interleukin } 6 \text { in } \\
\text { immortalized human keratinocytes. wound- } \\
\text { healing effects were evaluated in 3T3-swiss albino } \\
\text { mouse fibroblasts. }\end{array}$ & P. edulis & (Wedler et al., 2014) \\
\hline
\end{tabular}




\section{References:}

Akao, Y., Seki, N., Nakagawa, Y., Yi, H., Matsumoto, K., Ito, Y., Ito, K., Funaoka, M., Maruyama, W., Naoi, M. and Nozawa, Y., 2004. A highly bioactive lignophenol derivative from bamboo lignin exhibits a potent activity to suppress apoptosis induced by oxidative stress in human neuroblastoma SH-SY5Y cells. Bioorganic \& medicinal chemistry, 12(18), pp.4791-4801.

Cai, H., Hudson, E.A., Mann, P., Verschoyle, R.D., Greaves, P., Manson, M.M., Steward, W.P. and Gescher, A.J., 2004. Growth-inhibitory and cell cycle-arresting properties of the rice bran constituent tricin in human-derived breast cancer cells in vitro and in nude mice in vivo. British journal of cancer, 91(7), pp.1364-1371.

Chongtham, N., Bisht, M.S. and Haorongbam, S., 2011. Nutritional properties of bamboo shoots: potential and prospects for utilization as a health food. Comprehensive Reviews in Food Science and Food Safety, 10(3), pp.153-168.

Fu, X.C., Wang, M.W., Li, S.P. and Wang, H.L., 2006. Anti-apoptotic effect and the mechanism of orientin on ischaemic/reperfused myocardium. Journal of Asian natural products research, 8(3), pp.265-272.

Fujimura, M., Ideguchi, M., Minami, Y., Watanabe, K. and Tadera, K., 2005. Amino acid sequence and antimicrobial activity of chitin-binding peptides, Pp-AMP 1 and Pp-AMP 2, from Japanese bamboo shoots (Phyllostachys pubescens). Bioscience, biotechnology, and biochemistry, 69(3), pp.642645 .

He, S., Wang, X., Zhang, Y., Wang, J., Sun, H., Wang, J., Cao, X. and Ye, Y., 2016. Isolation and prebiotic activity of water-soluble polysaccharides fractions from the bamboo shoots (Phyllostachys praecox). Carbohydrate polymers, 151, pp.295-304.

Hu, C., Zhang, Y. and Kitts, D.D., 2000. Evaluation of antioxidant and prooxidant activities of bamboo Phyllostachys nigra var. Henonis leaf extract in vitro. Journal of Agricultural and Food Chemistry, 48(8), pp.3170-3176.

Hudson, E.A., Dinh, P.A., Kokubun, T., Simmonds, M.S. and Gescher, A., 2000. Characterization of potentially chemopreventive phenols in extracts of brown rice that inhibit the growth of human breast and colon cancer cells. Cancer Epidemiology and Prevention Biomarkers, 9(11), pp.1163-1170.

Jiao, J., Zhang, Y., Liu, C., Liu, J.E., Wu, X. and Zhang, Y., 2007. Separation and purification of tricin from an antioxidant product derived from bamboo leaves. Journal of agricultural and food chemistry, 55(25), pp.10086-10092.

Jiao, J., Zhang, Y., Lou, D., Wu, X. and Zhang, Y., 2007. Antihyperlipidemic and antihypertensive effect of a triterpenoid-rich extract from bamboo shavings and vasodilator effect of friedelin on phenylephrine-induced vasoconstriction in thoracic aortas of rats. Phytotherapy Research: An International Journal Devoted to Pharmacological and Toxicological Evaluation of Natural Product Derivatives, 21(12), pp.1135-1141.

Jin, Y.C., Yuan, K. and Zhang, J., 2011. Chemical composition, and antioxidant and antimicrobial activities of essential oil of Phyllostachys heterocycla cv. Pubescens varieties from China. Molecules, 16(5), pp.4318-4327.

Jung, S.H., Lee, J.M., Lee, H.J., Kim, C.Y., Lee, E.H. and Um, B.H., 2007. Aldose reductase and advanced glycation endproducts inhibitory effect of Phyllostachys nigra.Biological and Pharmaceutical Bulletin, 30(8), pp.1569-1572.

Katsuzaki, H., Sakai, K., Achiwa, Y., Imai, K. and Komiya, T., 1999. Isolation of antioxidative compounds from bamboo shoots sheath. Nippon Shokuhin Kagaku Kogaku Kaishi,46(7), pp.491493.

Koparde, A.A., Doijad, R.C. and Magdum, C.S., 2019. Natural products in drug discovery. Pharmacognosy-medicinal plants, pp.120.

Kweon, M.H., Hwang, H.J. and Sung, H.C., 2001. Identification and antioxidant activity of novel chlorogenic acid derivatives from bamboo (Phyllostachys edulis). Journal of agricultural and food chemistry, 49(10), pp.4646-4655.

Lee, H.J., Kim, K.A., Kang, K.D., Lee, E.H., Kim, C.Y., Um, B.H. and Jung, S.H., 2010. The compound isolated from the leaves of Phyllostachys nigra protects oxidative stress- 
induced retinal ganglion cells death. Food and chemical toxicology, 48(6), pp.1721-1727.

Lin, Y., Collier, A.C., Liu, W., Berry, M.J. and Panee, J., 2008. The inhibitory effect of bamboo extract on the development of 7, 12-dimethylbenz [a] anthracene (DMBA)-induced breast cancer. Phytotherapy Research: An International Journal Devoted to Pharmacological and Toxicological Evaluation of Natural Product Derivatives, 22(11), pp.1440-1445.

Liu, H., He, P., He, L., Li, Q., Cheng, J., Wang, Y., Yang, G. and Yang, B., 2018. Structure characterization and hypoglycemic activity of an arabinogalactan from Phyllostachys heterocycla bamboo shoot shell. Carbohydrate polymers, 201, pp.189-200.

Lu, B., Xia, D., Huang, W., Wu, X., Zhang, Y. and Yao, Y., 2010. Hypolipidemic effect of bamboo shoot oil ( $P$. pubescens) in Sprague-Dawley rats. Journal of Food Science, 75(6), pp.H205$\mathrm{H} 211$.

Mathur, S. and Hoskins, C., 2017. Drug development: Lessons from nature. Biomedical reports, 6(6), pp.612-614.

Mu, J., Uehara, T., Li, J. and Furuno, T., 2004. Identification and evaluation of antioxidant activities of bamboo extracts. Forestry Studies in China, 6(2), p.1.

Nishina, A., Hasegawa, K., Uchibori, T., Seino, H. and Osawa, T., 1991. 2, 6-Dimethoxy-pbenzoquinone as an antibacterial substance in the bark of Phyllostachys heterocycla var. Pubescens, a species of thick-stemmed bamboo. Journal of agricultural and food chemistry, 39(2), pp.266-269.

Park, E.J. and Jhon, D.Y., 2010. The antioxidant, angiotensin converting enzyme inhibition activity, and phenolic compounds of bamboo shoot extracts. LWT-Food Science and Technology, 43(4), pp.655-659.

Park, H.S., Lim, J.H., Kim, H.J., Choi, H.J. and Lee, I.S., 2007. Antioxidant flavone glycosides from the leaves of Sasa borealis. Archives of pharmacal research, 30(2), pp.161-166.

Quitain, A.T., Katoh, S. and Moriyoshi, T., 2004. Isolation of antimicrobials and antioxidants from moso-bamboo (Phyllostachys heterocycla) by supercritical $\mathrm{CO} 2$ extraction and subsequent hydrothermal treatment of the residues. Industrial \& engineering chemistry research,43(4), pp.10561060.

Shang, Y.F., Kim, S.M. and Um, B.H., 2014. Optimisation of pressurised liquid extraction of antioxidants from black bamboo leaves. Food Chemistry, 154, pp.164-170.

Suga, A., Takaishi, Y., Goto, S., Munakata, T., Yamauchi, I. and Kogure, K., 2003. Two lignan dimers from bamboo stems (Phyllostachys edulis). Phytochemistry, 64(5), pp.991-996.

Tanaka, A., Kim, H.J., Oda, S., Shimizu, K. and Kondo, R., 2011. Antibacterial activity of moso bamboo shoot skin (Phyllostachys pubescens) against Staphylococcus aureus. Journal of wood science, 57(6), pp.542-544.

Tanaka, A., Shimizu, K. and Kondo, R., 2013. Antibacterial compounds from shoot skins of moso bamboo (Phyllostachys pubescens). Journal of wood science, 59(2), pp.155-159.

Tanaka, A., Zhu, Q., Tan, H., Horiba, H., Ohnuki, K., Mori, Y., Yamauchi, R., Ishikawa, H., Iwamoto, A., Kawahara, H. and Shimizu, K., 2014. Biological activities and phytochemical profiles of extracts from different parts of bamboo (Phyllostachys pubescens). Molecules, 19(6), pp.8238-8260.

Tao, C., Wang, Y., Zhang, X., Li, L., Wu, Y., Han, X., Jiang, X. and Lv, Z., 2019. Mechanism of action of essential oils extracted from bamboo (Phyllostachys heterocycla cv. pubescens) leaves: chemical composition and antimicrobial activity against four food-related microorganisms. BioResources, 14(1), pp.14191434.

Tao, C., Wu, J., Liu, Y., Liu, M., Yang, R. and Lv, Z., 2018. Antimicrobial activities of bamboo (Phyllostachys heterocycla cv. Pubescens) leaf essential oil and its major components. European Food Research and Technology, 244(5), pp.881891.

Veeresham, C., 2012. Natural products derived from plants as a source of drugs. Journal of advanced pharmaceutical technology \& research, 3(4), p.200.

Wedler, J., Daubitz, T., Schlotterbeck, G. and Butterweck, V., 2014. In vitro anti-inflammatory and wound-healing potential of a Phyllostachys edulis leaf extract-identification of isoorientin as 
an active compound. Planta medica, 80(18), pp.1678-1684.

Xiao, Z., Zhang, Q., Dai, J., Wang, X., Yang, Q., Cai, C., Mao, J. and Ge, Q., 2020. Structural characterization, antioxidant and antimicrobial activity of water-soluble polysaccharides from bamboo (Phyllostachys pubescens Mazel) leaves. International journal of biological macromolecules, 142, pp.432-442.

Xu, X.B., Jiang, H., Sun, J., Tang, F., Guo, X.F. and Wang, J., 2016. Chemical constituents and antioxidant properties of Phyllostachys prominens Gramineae (WY Xiong) leaf extracts. Tropical Journal of Pharmaceutical Research, 15(3), pp.569575.
Zhang, Y., Jiao, J., Liu, C., Wu, X. and Zhang, Y., 2008. Isolation and purification of four flavone Cglycosides from antioxidant of bamboo leaves by macroporous resin column chromatography and preparative high-performance liquid chromatography. Food chemistry, 107(3), pp.13261336.

Zhang, Z., Wang, X., Yu, S. and Zhao, M., 2011. Isolation and antioxidant activities of polysaccharides extracted from the shoots of Phyllostachys edulis (Carr.). International journal of biological macromolecules, 49(4), pp.454-457. 